\title{
New record of the red prickly sea star Paulia horrida (Gray, 1840), Asterodiscididae, in the north of Chile
}

\author{
Felipe Méndez-Abarca ${ }^{1 *}$, Enrique A. Mundaca² and Renzo Pepe-Victoriano ${ }^{1}$
}

\begin{abstract}
We report the capture of a single specimen of the species Paulia horrida Gray, 1840, off the coast of Arica, in the Arica and Parinacota Region, Northern Chile. This finding extends the currently known distributional range of the species by 2,434 km towards the south, since the southernmost known area for this species corresponds to Punta Sal, Peru. We discuss the importance of finding this relatively unknown species in Chile and the need to continue sampling to confirm the continuous distributional range of the species between the south of Peru and the north of Chile.
\end{abstract}

Keywords: Arica, Distribution, Northern Chile, Pacific coast, Peru, Starfish, Paulia horrida.

\section{Introduction}

Echinodermata is a phylum of coelomate marine animals, mostly benthic and with a wide bathymetric distributional range (Caso 1961); (Harrison 1994), ranging from 0 to more than $1500 \mathrm{~m}$ as the case of, for instance, Antarctic echinoderms (Moles et al. 2015). The class Asteroidea includes 1890 currently described species (Mah and Blake 2012), commonly known as 'starfish' or 'sea stars' due to their body shape, as it resembles the shape of a star (Hyman 1955).

The family Asterodiscididae comprises three genera: Amphiaster Verrill 1868, Asterodiscides A. M. Clark 1974 and Paulia Gray 1840. Asterodiscides inhabits shallow to deep waters, and the genera Amphiaster and Pauliaoccur mainly in shallow coastal waters (Rowe 1985); (Oguro 1991). Within this family,Paulia horridahas a wide geographic distributional range, occurring from the Baja California Peninsula, in Mexico, to the locality of Punta Sal, in Peru (Clark 1910); (Rowe 1977); (Hooker and Solís-Marín 2011) (Fig.1). Morphologically, $P$.

\footnotetext{
* Correspondence: felipe.mendez@northamerican.cl

${ }^{1}$ Facultad de Recursos Naturales Renovables, Universidad Arturo Prat, Arica, Chile

Full list of author information is available at the end of the article
}

horridais basically characterised by its thick conical spines covering the aboral area and its intense vermilion-red colour in living specimens (Hooker and Solís-Marín 2011).

In this report, we expand the currently known distribution of Paulia horrida to a new southernmost locality. We then discuss the importance of finding this species in Chile and the need to continue sampling to document the distributional range of this species more thoroughly, particularly focusing on the gap between the north of Peru and north of Chile.

\section{Materials and methods}

The specimen was collected, by autonomous diving, off the coast of Arica (18.4746 ${ }^{\circ}$ S; $070.2894^{\circ}$ W), Parinacota Region, Northern Chile. The specimen was collected alive, measured with callipers, then submerged in fresh water following the method of (Quijada 1911) for two hours to anesthetise it; and fixed in $95 \%$ alcohol in a closed plastic tray to induce dehydration. The specimen was taken to the laboratory and dried in a taxidermy oven at $80^{\circ} \mathrm{C}$ for $2 \mathrm{~h}$. Finally, the specimen was photographed using a Canon PowerShot $\odot$ SX60 HS camera and incorporated to the collection of marine

(c) The Author(s). 2021 Open Access This article is licensed under a Creative Commons Attribution 4.0 International License, which permits use, sharing, adaptation, distribution and reproduction in any medium or format, as long as you give appropriate credit to the original author(s) and the source, provide a link to the Creative Commons licence, and indicate if changes were made. The images or other third party material in this article are included in the article's Creative Commons licence, unless indicated otherwise in a credit line to the material. If material is not included in the article's Creative Commons licence and your intended use is not permitted by statutory regulation or exceeds the permitted use, you will need to obtain permission directly from the copyright holder. To view a copy of this licence, visit http://creativecommons.org/licenses/by/4.0/. 


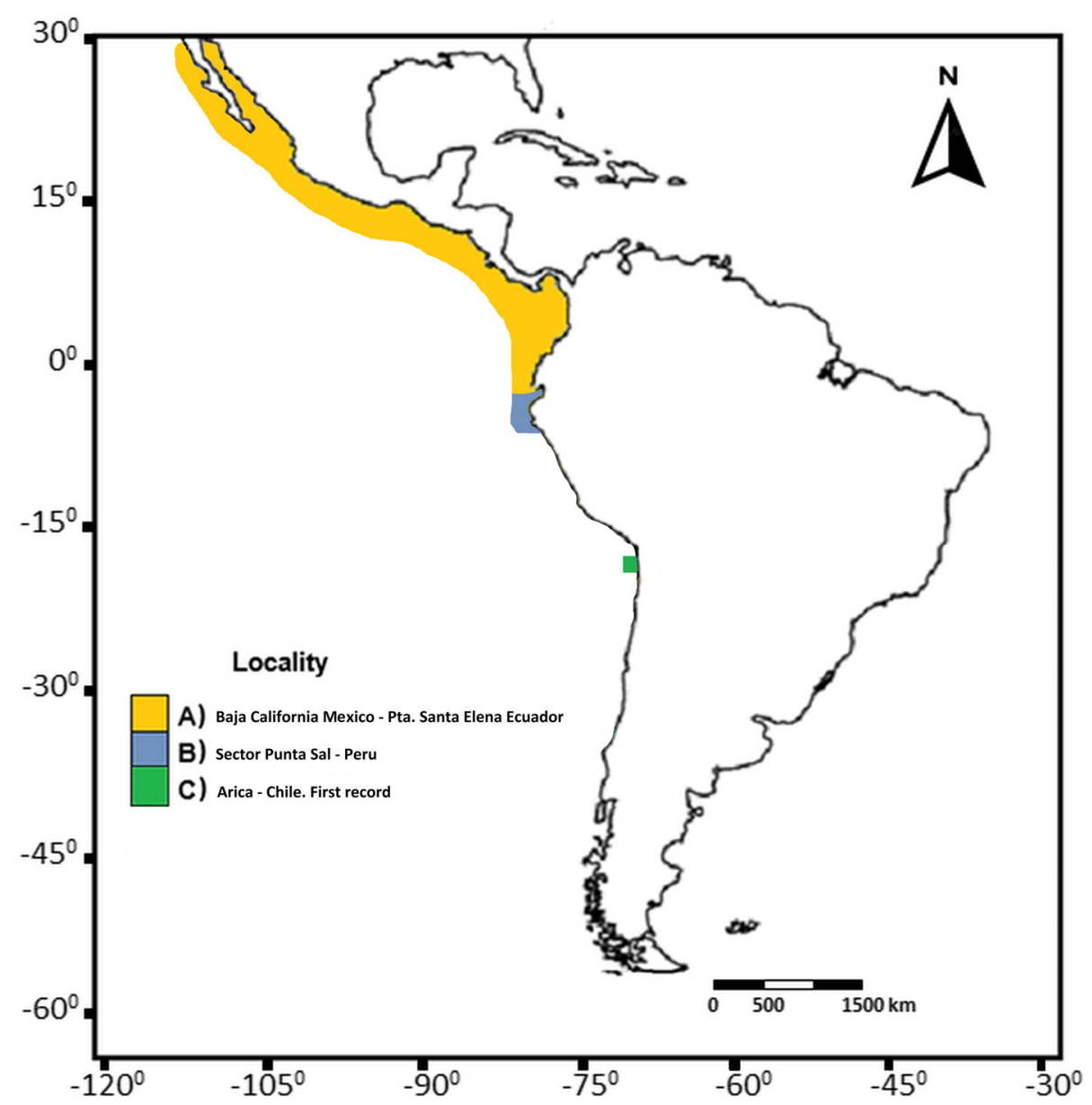

Fig. 1 Distribution map of the sea star Paulia horrida along the Pacific coast of America showing historical records of the species and the new reported locality. Letters in the figure represent records made by the following authors: (A)(Clark 1910,1993);(B)(Hooker and Solís-Marín 2011);(C) Present study

invertebrates of the museum 'Vida Salvaje-Museo Vivo', of the Animal Kingdom Foundation (Fundación Reino Animal), in Arica, Chile. A label was applied to the specimen (COLEQUISIL088FRA) acronym of "Collection of equinoderms: Number 088: Animal Kingdom Foundation)".

\section{Results}

New record for Chile of the species $P$. horrida. The specimen was collected at a depth of $13 \mathrm{~m}$, on a rocky substrate isolated by sand. One adult specimen, sex undetermined; radius length $R=65 \mathrm{~mm}$ (we used the major radius length $\mathrm{R}$ measured as the distance from the centre of the oral disk to the tip of the arm); Arica, Arica province, Region of Arica and Parinacota; 12 January 2018; specimen collected alive at $13 \mathrm{~m}$ deep on a rocky substrate, surrounded by a sandy bottom, offshore of the Alacran peninsula area $\left(18.4802^{\circ} \mathrm{S} ; 070.3319^{\circ} \mathrm{W}\right)$. Figure $2 \mathrm{~A}-\mathrm{B}$.
The identification of the specimen was based on the taxonomic characters described by (Hooker and Solís-Marín 2011). Disc well developed, slightly elevated. Ventral region flattened; with five wide triangular arms, strong, conical, with spines covering the abactinal (aboral) surface. Abactinal plates with numerous pores through which the papulae emerge. Actinal surface with tessellated actinal plates, each with a bulge surrounded by small granules. Supramarginal plates with large spherical spines distinctive of the species. Narrow ambulacral groove. Interambulacral plates with a row of small, finger-like, internal spines and an outer series of two larger spines on each plate. Actinal surface with tessellated actinal plates, each with a bulge surrounded by small granules. The specimen exhibited an intense redvermilion colouration while alive, becoming pale orange after being fixed and dried.

\section{Discussion}

In general, Paulia horrida is a poorly known species, with no records of its life cycle and ecology. 


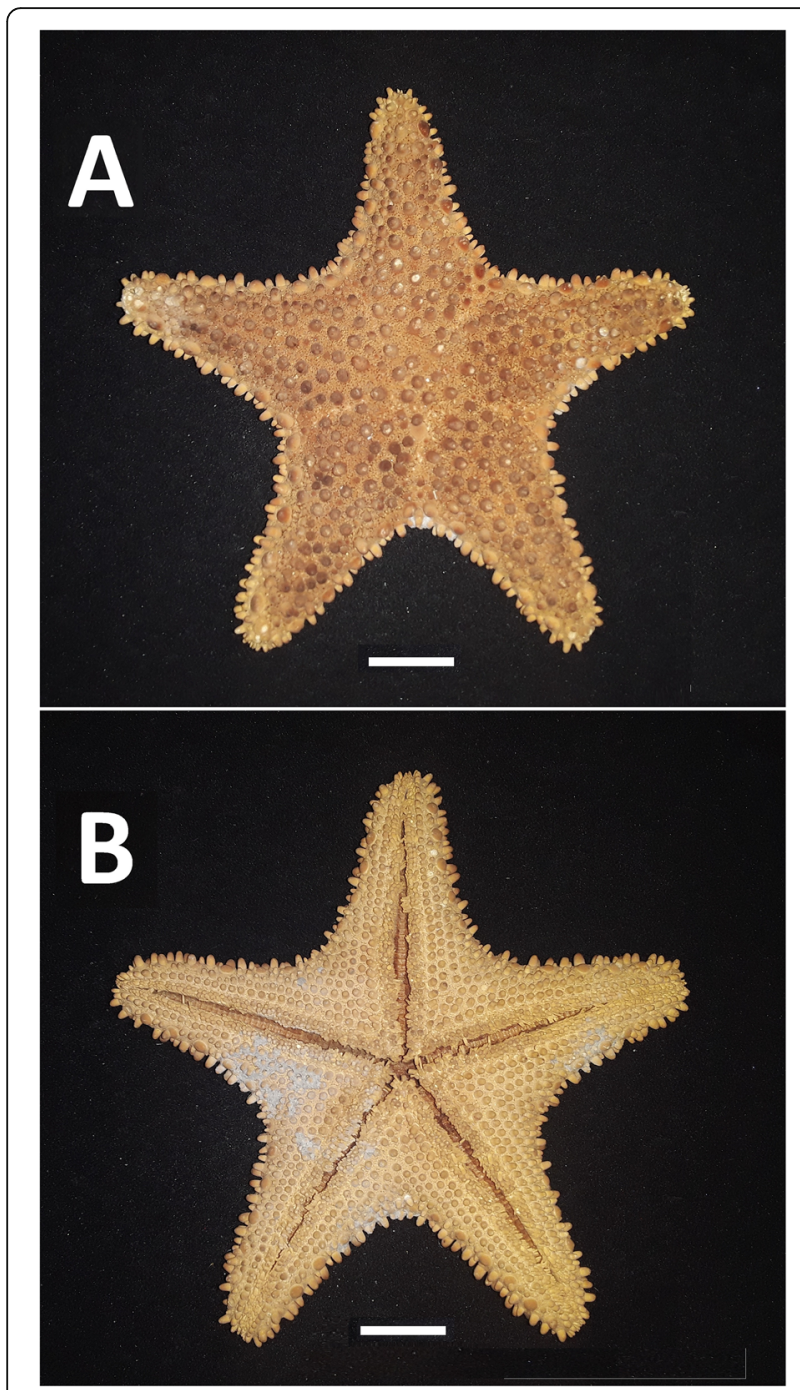

Fig. 2 Dried specimen of the sea star Paulia horrida collected in Arica, Chile. (A) Aboral and (B) oral view Scale bar $=2 \mathrm{~cm}$

The first record of $P$. horridawas described by H.L. (Clark 1910) comprised the area of Punta Santa Elena, in Ecuador, extending towards the Galapagos Islands. Subsequently, (Rowe 1977) hypothesised that P. horrida was potentially present in the Peruvian coast, which was later confirmed by Hooker and Solís-Marín (2011), who collected an $R=84 \mathrm{~mm}$ specimen at a depth of $33 \mathrm{~m}$ on a rocky reef in Punta Sal, northern Peru. Furthermore, A.M. (Clark 1993) incorporated some localities in his checklist suggesting Baja California, Mexico, as the northernmost distributional limit of the species, also including the localities of Isla Clarión and Isla del Coco, both located in Costa Rica. Finally, (Maluf 1987) broadened the distribution of the species confirming the Galapagos Islands as part of the distributional range of $P$. horrida.
In this report, a single specimen of $P$. horrida was collected off the coast of northern Chile, expanding the already known geographical distribution of the species by approximately $2,434 \mathrm{~km}$ towards the South. The specimen had an $R=65 \mathrm{~mm}$, which provides some insights of the size variation of the species when comparing it with other records such as, for example, Hooker and Solís-Marín (2011) who reported a larger, $R=84 \mathrm{~mm}$ radius, specimen.

The discovery of $P$. horrida in Chilean waters allows us to incorporate it to the Chilean asteroid fauna, opening the possibility of its presence at even southern latitudes along the Chilean coasts. This needs to be confirmed through further sampling of the species in such latitudes. Moreover, in light of the current scenario of global biodiversity loss and the necessity to carry out effective conservation measures, this expansion of the distributional range of this species represents an invaluable opportunity to gain further knowledge of this species.

\section{Conclusions}

A specimen of $\mathrm{P}$. horrida was collected in waters of northern Chile, off the coast of the city of Arica. This capture corresponds to the first record of this species in this area of the Pacific. The single specimen does not necessarily indicate a population settled in this area, although future collection days could corroborate or discard this hypothesis.

\section{Acknowledgements \\ We thank the reviewers and editor for their comments and suggestions that allowed us to improve the quality of this paper. We would also like to thank to the Programa de Magíster en Acuicultura, Mención Recursos Hidrobiológicos y Mención Acuiponía, Universidad Arturo Prat, Chile; to Lorena Avilés-Arredondo for reviewing the structure of the manuscript and to Dr. Mariana Lazzaro-Salazar for proofreading the manuscript.}

\section{Authors' contributions}

FM-A performed field samplings, taxonomical identifications and paper writing; EAM performed scientific review, contributed to paper writing and translated it into English; RP-V assisted the paper writing and review. The author(s) read and approved the final manuscript.

\section{Funding}

Not applicable.

\section{Availability of data and materials}

The sample is available at the equinoderms collection belonging to the "Animal Kingdom Foundation (specimen record: COLEQUISIL088FRA)".

\section{Declarations}

Ethics approval and consent to participate Not applicable.

\section{Consent for publication}

Not applicable.

Competing interests

The authors declare that they have no competing interests. 


\section{Author details}

${ }^{1}$ Facultad de Recursos Naturales Renovables, Universidad Arturo Prat, Arica, Chile. ${ }^{2}$ Facultad de Ciencias Agrarias y Forestales, Escuela de 6 Agronomía, Universidad Católica del Maule, Curicó, Chile.

Received: 19 June 2021 Accepted: 7 October 2021

Published online: 29 October 2021

\section{References}

Caso ME. Estado Actual de los Conocimientos acerca de los Equinodermos de México. Tesis Doctoral. Universidad Autónoma de México. México, D. F. 1961 p. 338

Clark AM. An index of names of recent Asteroidea, part 2: Valvatida. Echinoderm Studies. 1993:4:187-366.

Clark HL. The Echinoderms of Peru. Bulletin of the Museum of Comparative Zoology at Harvard University. 1910. 52(17):321-358. https://doi.org/10.5962/ bhl.title.24250.

Gray JE. XXXII. A synopsis of the genera and species of the class Hypostoma (Asterias, Linnaeus). Ann. Mag. Nat. Hist. 1840. 6: 275-290.

Harrison FW, Chia FS. Microscopic Anatomy of Invertebrates. Vol. 14. Echinodermata. Wiley-Liss. 1994. p.510.

Hooker Y, Solís-Marín FA. Tres nuevos registros de asteroideos (Echinodermata: Asteroidea) de Perú. Rev peru biol. 2011;18(3):319-24. https://doi.org/10.153 81/rpb.v18i3.444.

Hyman LH. The Invertebrates: Echinodermata. The coelomate bilateralia. Vol. IV: McGraw-Hill; 1955. p. 763.

Ludwig H. Asteroidea. Mem. Mus. Comp Zool̈ogy Harv. 1905;32:vii-xii.

Mah CL, Blake DB. Global diversity and phylogeny of the Asteroidea (Echinodermata). PLOS ONE. 2012;7(4):e35644.

Maluf LY. Classification and distribution of the Central Eastern Pacific echinoderms. PhD thesis, University of Arizona, Flagstaff, USA. 1987. p.307.

Moles J, Figuerola B, Campanya-Llovet N, Monleón-Getino T, Taboada S, Avila C. Distribution patterns in Antarctic and Subantarctic echinoderms. Polar Biol. 2015;38(6):799-813.

Müller J, Troschel FH. System der Asteriden. Friedrich Viewegund Sohn, Braunschweig. 1842. p.134.

Oguro C. Asterodiscides japonicus n. sp, Echinoderms from Continental Shelf and Slope around Japan. Vol. 2. Tokyo: Japan Fisheries Resource Conservation Association; 1991. pp. 75-86.

Perrier E. Révision de la collection de Stellerides de Museum d'Histoire Naturelle de Paris. 1875. p.384.

Quijada B. Métodos usados en las estaciones de biolojia marina para la conservación de los organismos acuáticos. Bol Mus Nac Hist Nat Santiago de Chile. 1911;3:99-145.

Rowe F. A new family of Asteroidea (Echinodermata), with the description of five new species and one new subspecies of Asterodiscides. Records of the Australian Museum. 1977;31(5):187-233.

Rowe FWE. Six new species of Asterodiscides A. M. Clark (Echinodermata, Asteroidea), with a discussion of the origin and distribution of the Asterodiscididae and other "amphi-Pacific" echinoderms. Bulletin du Muséum national d'Histoire naturelle, Paris, 4e sér, Sect. 1985. A7 (3): 531-577.

\section{Publisher's Note}

Springer Nature remains neutral with regard to jurisdictional claims in published maps and institutional affiliations. 